$\begin{array}{ll}\text { Abstracta Iranica } & \begin{array}{l}\text { Abstracta Iranica } \\ \text { Revue bibliographique pour le domaine irano-aryen }\end{array} \\ & \text { Volume } \mathbf{2 6} \mid \mathbf{2 0 0 5} \\ & \text { Comptes rendus des publications de } \mathbf{2 0 0 3}\end{array}$

\title{
«Il vetri di Hatra ». Topoi 10,1 (2000) [2002], Dossier Hatra, pp. 253-265, 29 figs.
}

\section{Karin Mosig-Walburg}

\section{(2) OpenEdition}

Édition électronique

URL : http://journals.openedition.org/abstractairanica/3458

ISSN : 1961-960X

\section{Éditeur :}

CNRS (UMR 7528 Mondes iraniens et indiens), Éditions de l'IFRI

Édition imprimée

Date de publication : 15 mai 2005

ISSN : 0240-8910

\section{Référence électronique}

Karin Mosig-Walburg, « « Il vetri di Hatra ». Topoi 10,1 (2000) [2002], Dossier Hatra, pp. 253-265, 29

figs. », Abstracta Iranica [En ligne], Volume 26 | 2005, document 151, mis en ligne le 08 décembre 2005, consulté le 25 septembre 2020. URL : http://journals.openedition.org/abstractairanica/3458

Ce document a été généré automatiquement le 25 septembre 2020.

Tous droits réservés 


\title{
«Il vetri di Hatra ». Topoi 10,1 (2000) [2002], Dossier Hatra, pp. 253-265, 29 figs.
}

\author{
Karin Mosig-Walburg
}

1 Analyse des trouvailles en verre faites au cours des fouilles italiennes entre 1987-1995 dans l'édifice A. La verrerie témoigne des éléments mésopotamiens et occidentaux.

INDEX

Thèmes : 3.2.3. Séleucides, Parthes et Sassanides

\section{AUTEURS}

KARIN MOSIG-WALBURG

Université de Francfort 